\title{
Young tectonic and halokinetic movements in the North-German-Basin: its effect on formation of modern rivers and surface morphology
}

\author{
F. Sirocko ${ }^{1}$, T. Szeder ${ }^{1}$, C. Seelos ${ }^{1}$, R. Lehne ${ }^{1}$, B. Rein ${ }^{1}$, \\ W.M. Schneider ${ }^{2} \&$ M. Dimke ${ }^{2}$ \\ 1 Institute for Geoscience, Johannes Gutenberg-Unversity Mainz, 55099 Mainz, Germany \\ 2 RWE/DEA AG für Mineralöl und Chemie, Überseering 40,22297 Hamburg, Germany
}

Manuscript received: January 2001; accepted: February 2002

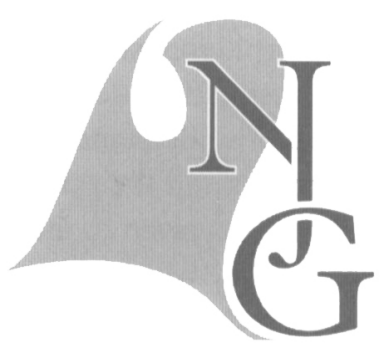

\begin{abstract}
Field mapping of fluvial terraces, aerial photographs, ground penetrating radar and seismic data from gas and oil exploration were used at four different locations to detect young tectonic and halokinetic movements in the North-German-Basin.

i) The course of the Rivers Weser and Aller follow precisely a shallow Tertiary graben on the northwestern flank of the Verden salt diapir. Recent local depressions and vegetation anomalies on the alluvial plain have the same orientation as the strike direction of the faults at subsurface depth. Apparently, the river follows tectonic lines, and thus the river sediments can be used for the interpretation of recent crustal movements.

ii) The Wedehof diapir, in contrast, is topped by a local topographic high which follows exactly the shape of the underlying salt. Either the diapir formed an obstacle for the advance of the continental glaciers or one has to assume halokinetic uplift of more than $50 \mathrm{~m}$ during the post-Saalian Pleistocene. Either way, the Wedehof diapir shows control of the modern surface morphology by halokinesis.

iii) The course of the river Hunte, in contrast, outside the area of salt diapirism, shows anomalies of incision and terrace width over a local updoming caused by tectonic inversion of distinct blocks in the basin. The confluence of several tributaries of the Hunte lies exactly over the updoming of Barnstorf. Thus, the rivers do not avoid the local high, but focus in this area, which is characterised by a graben on top of the domestructure, as visible in seismic profiles. Again, tectonism controls river development.

iv) The last case study is from Lake Plön, where seismic profiles reveal that linear shorelines of the lake parallel the flanks of two local graben structures of Tertiary age. It is apparent that the Weichselian glaciers that formed the lake and the surrounding moraines interacted with the existing grabens.

The Tertiary morphology in the North German basin was apparently draped by Quaternary glacial deposits, but rivers and lakes that dominate the topography of the modern landscape still reflect the geodynamic centers of Tertiary tectonism and halokinesis. Faults from the depth of the Tertiary penetrate the Quaternary strata and allow upward fluid migration, which becomes visible on aerial photographs as linear vegetation anomalies.
\end{abstract}

Keywords: halokinetic, North-German-Basin, rivers, terraces, surface morphology

\section{Introduction}

The lowlands of Northern Germany have been reached by Scandinavian inland glaciers at least four times during Middle and Late Pleistocene. The southernmost glacier extent occurred during the Elsterian and was followed by the ice advances of the
Drenthe and Warthe stages during the Saalian glaciation (Caspers et al., 1995). Their moraines cover the area between the rivers Elbe and Weser (Fig. 1) and have an age of more than 125,000 yrs BP. The last glaciation (Weichselian ice age, about 20,000 years ago) was restricted to north of the river Elbe from where the ice retreated some 12,000 years ago. Tills 
and meltwater sands of these glaciations build the uppermost strata (several tens of meters up to more than $500 \mathrm{~m}$ thickness) in the North German basin (Liedtke, 1980).

This tectonic basin extends from Poland through the states of Brandenburg, Lower Saxony, Schleswig Holstein, into the North Sea and the Netherlands; and reaches north-south from Scandinavia to the Variscan mountains of middle Germany. Subsidence started in the early Permian about $290 \mathrm{Ma}$ ago. The deepest parts of the basin are today filled by more than $8 \mathrm{~km}$ of sediments, with an average depth of about $5 \mathrm{~km}$. The Mesozoic tectonic history of the basin subdivides it into several blocks with phases of inversion, resulting in a complex structural pattern (e.g. Walter, 1992).

The shallow, but continuously subsiding basin, was filled with more than $1000 \mathrm{~m}$ of salt during the late Permian. The salt became mobile along extensional faults aligned SSW-NNE and SE-NW and developed to mature salt diapirs during the middle Jurassic, late Cretaceous and during most of the Tertiary (Walter, 1992). These saltdiapirs characterise most parts of northern Germany (Fig. 1). The Quaternary history of these halokinetic structures, however, is largely unknown. Apparently, the caprock of some diapirs (Lüneburg, Bad Segeberg) penetrate the glacial sands and moraines, and modern uplift rates are at least 0.5 $\mathrm{mm} /$ year in Bad Segeberg (Jaritz, 1980; Ross, 1998). Other diapirs have been quiescent since the Late Cretaceous and do no break the base of the Tertiary.

Postglacial movements in the upper crust of the basin were most likely caused by active diapirism, but the present day stress field, crustal processes, ice-isostatic adjustments after retreat of the large inland glaciers, compaction, thermal contrasts, and fluid movements are other candidates for causing young movements near the land surface. Seismicity is very rare in the modern basin, and is mostly attributed to processes in the diapir caprock (Leydecker, 1999). The rate of modern crustal movements was quantified in east Germany by repeated geodetic fine-levelling revealing subsidence rates between 0.5 and 2.5 $\mathrm{mm} /$ year (Ihde et al., 1987), i.e. of the same order as halokinetic movements in salt diapirs $(0.5 \mathrm{~mm} /$ year, Jaritz, 1980). Information about modern crustal movements in west Germany is very rare. There are, however, abundant seismic data from oil and gas exploration. The first synthesis on the deep structure of the basin from this data source was recently published in the Tectonic Atlas of NW Germany (1996). This atlas shows the depth of various layers from the Early Permian to the late Tertiary (e.g. Fig. 2).

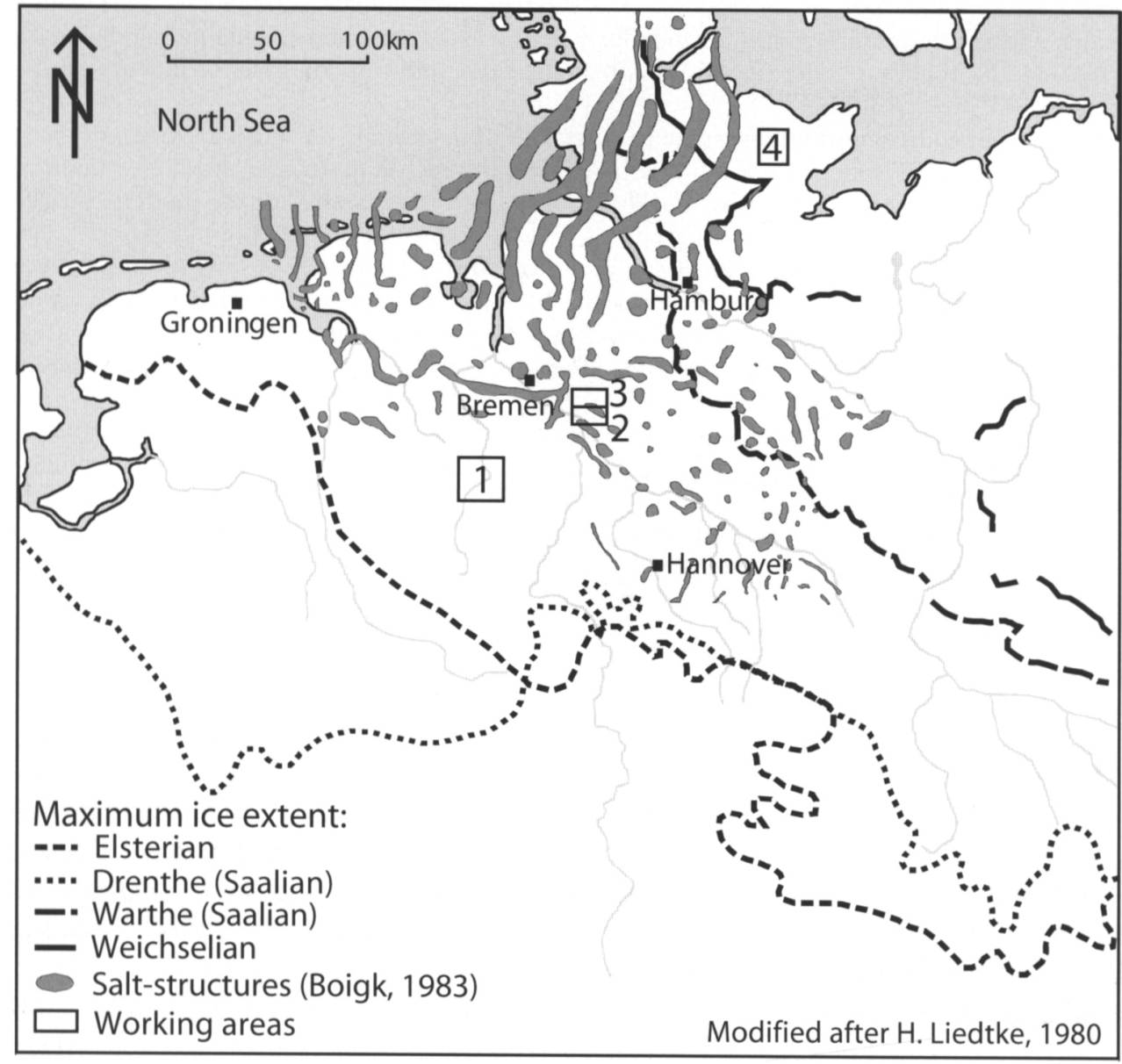

Fig. 1. Working areas. Endmoraines after Liedtke (1981) and salt diapirs according to Tectonic Atlas of NW Germany (1996). 


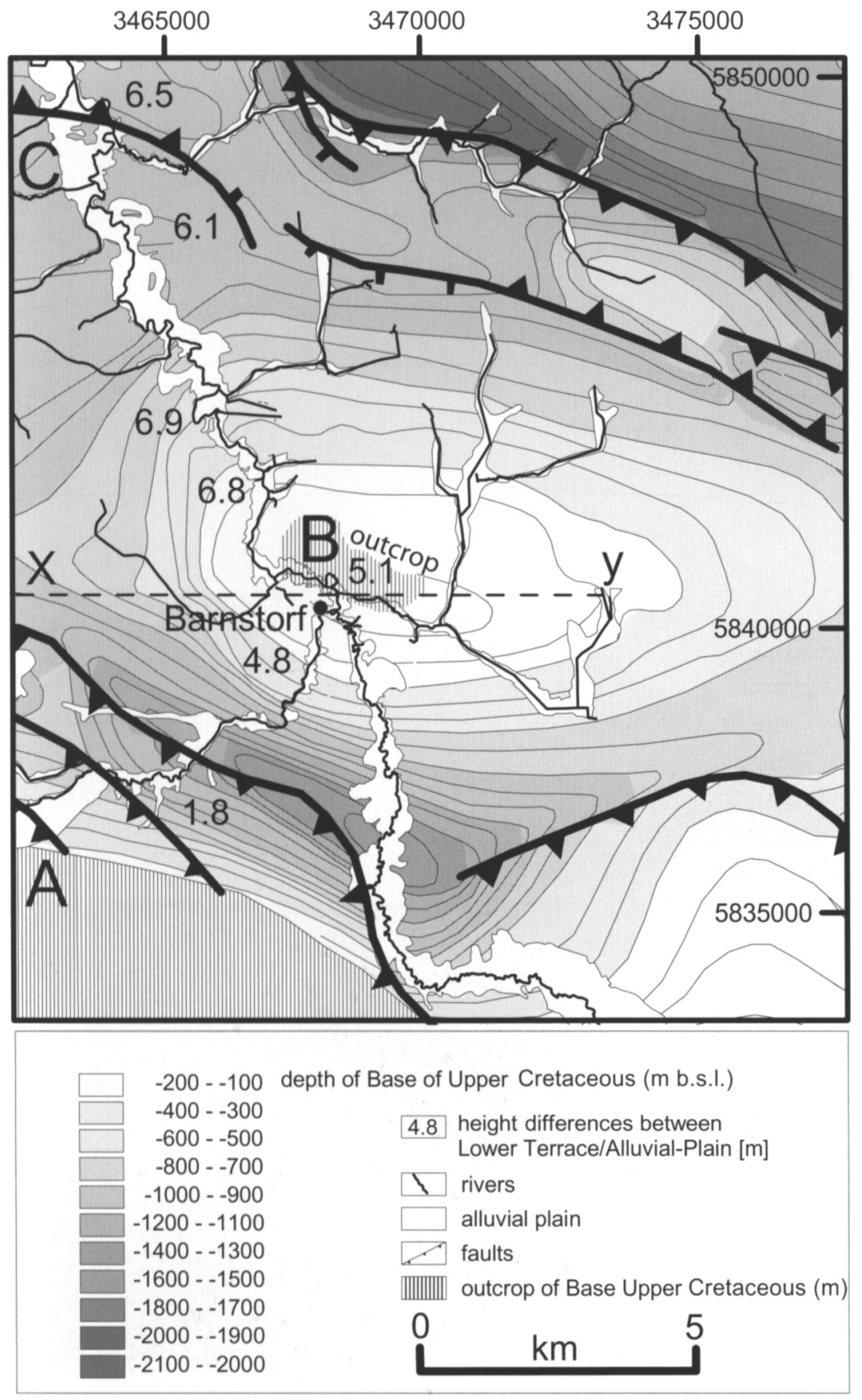

Fig. 2. Structural contour map of working area 1; depth Base Upper Cretaceous after Tectonic Atlas of NW-Germany (1996). The alluvial plain of the river Hunte and its tributaries are dotted. Numbers indicate the average height differences between the Weichselian lower terrace and the Holocene alluvial plain. The letters A-C mark the direction of the longitudinal profile (Fig. 3a and b). The position of the 3-Dimensional-seismic-data profile is given by the dashed line, letters $\mathrm{x}$-y (Fig. 3c).

It is the aim of this paper to present methods for detecting young crustal movements at the land surface and providing evidence that modern rivers and lakes largely reflect lines and areas of crustal instability. Four study sites were selected (Fig. 1):

1. The alluvial plain of the river Hunte which transects an area of local updoming and large tectonic fault lines at the southern border of the basin.

2. The salt diapir of Verden under the flat Lower terrace sediments of the river Aller and Weser in an area dominated by Saalian meltwater sands.

3. The salt diapir of Wedehof, which is topped by a local morainic (Saalian) hill of high elevation with evidence for subrosion (erosion of salt by groundwater).
4. The lake 'Großer Plöner See' in the belt of endmoraines of the Weichselian glaciation in Schleswig Holstein.

\section{Methods}

To detect tectonic structures in the surface morphology we used field mapping of vegetation anomalies and small depressions, ground penetrating radar to survey the upper $10 \mathrm{~m}$, and 3-dimensional reflection seismic to survey the depth interval $4000-400 \mathrm{~m}$. Satellite data and air photographs were used to detect lineaments.

The ground penetrating radar is a RAMAC/GPR from the Mala Geoscience company with $25 \mathrm{MHz}$, 
$50 \mathrm{MHz}$ and $100 \mathrm{MHz}$ unshielded antennas. The best possible resolution is $1 \mathrm{~m}$ for the low frequency-, and $10 \mathrm{~cm}$ for the high frequency antenna. It is impossible to reach penetration deeper than the ground water table. 3-dimensional seismic data were kindly provided by RWE/DEA for the entire field of Völkersen (with both the Wedehof and Verden salt diapirs), about $20 \mathrm{~km}$ southeast of Bremen. The data allow detection of lateral and vertical movements larger than $25 \mathrm{~m}$. Aerial panchromatic photographs allow detection of surface lightness anomalies with less than $1 \mathrm{~m}$ width. All data are compiled in the GIS system ArcView after preprocessing and enhancing the remote sensing data.

\section{Regional uplift (tectonic updoming)}

A GIS synthesis of historical topographic maps (Preussische Messtischblätter, 1898) and the Tectonic Atlas of NW-Germany (1996) was used to detect young morphological structures in the Late Weichselian Lower Terrace of the river Hunte (working area 1, Fig. 1). The historical maps were used because the course of the river Hunte was straightened about 40 years ago and natural slopes were smoothed. Accordingly, the old maps present a landscape largely without human influence. Fig. 2 presents the width of the alluvial plain (dotted field), and numbers give the height-difference between the Weichselian lower terrace and the Holocene alluvial-plain, thus showing the incision of the river since about 12,000 years ago. The background reproduces the depth of the base of the Upper Cretaceous, which is found up to $2000 \mathrm{~m}$ below the surface and reaches a local maximum of $100 \mathrm{~m}$ b.s.l. near the town of Barnstorf. The base of the Tertiary is displaced over the updoming $(100 \mathrm{~m}$ b.s.l., Fig. 3b). There is no salt diapir below this updoming, accordingly it is of tectonic origin and already visible at the Jurassic to Cretaceous boundary (Tectonic Atlas of NW-Germany, 1996).

Strong incision of the river started in the area of updoming and extends towards the north with 5-7 $\mathrm{m}$ height difference between the lower terrace and alluvial plain (Fig. 3a). On top of the dome is the strongest knickpoint in the longitudinal profile of the river Hunte (grey bar in Fig. 3a, b), i.e. the gradient of the alluvial plain increases strongly over the updoming. In addition, the width of the alluvialplain of the river Hunte and is tributaries is smallest on top of the dome. Directly above the updoming is the confluence of the river Hunte with two tributaries. Therefore, all Holocene river anomalies focus on top and north of the updoming, and could be most likely explained by an active Holocene uplift in
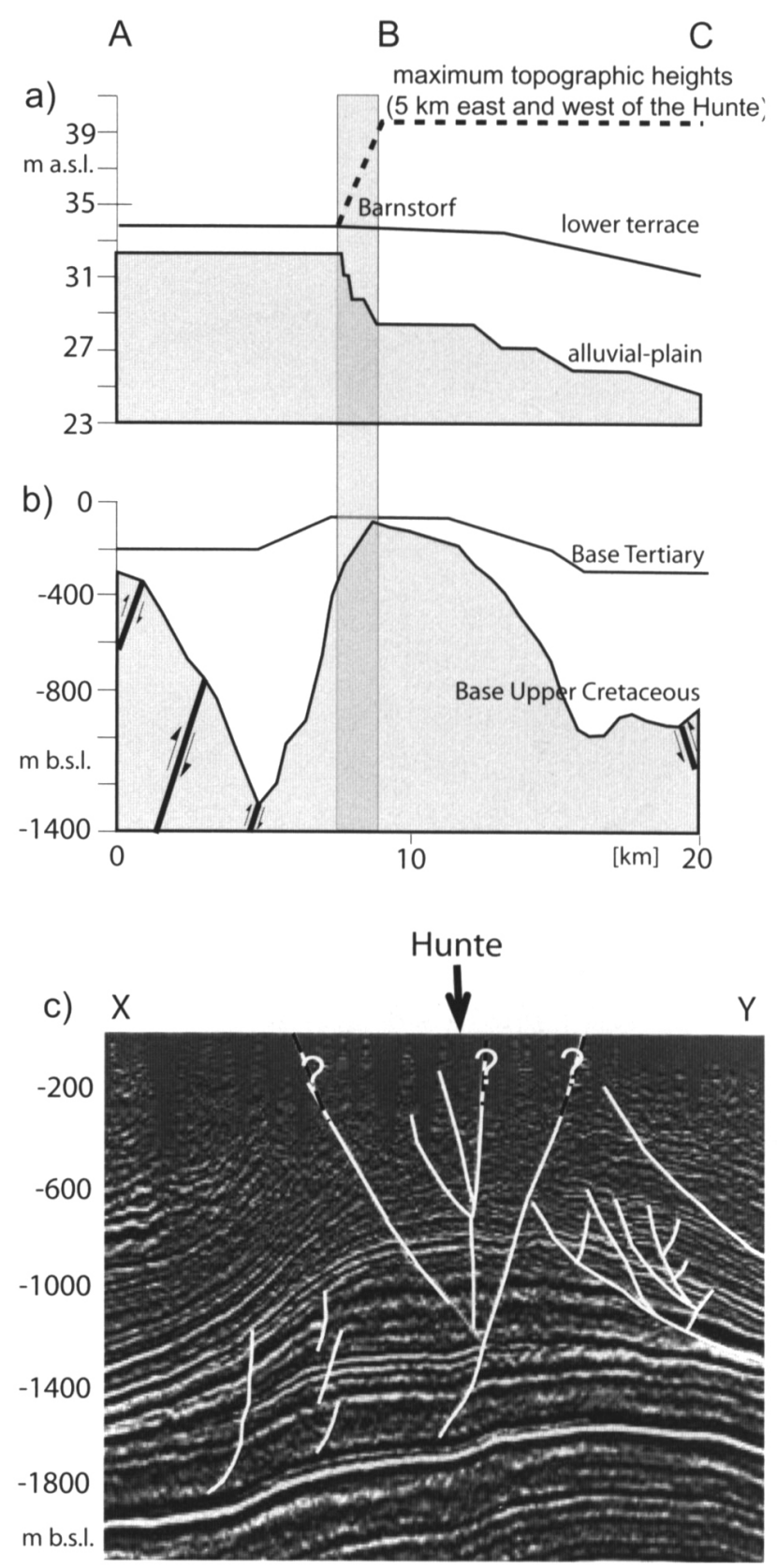

Fig. 3. Longitudinal transects along the alluvial-plain of the Hunte river (see Fig 2, transect line A-B-C). a) River topography, b) depth of the Base of the Upper Cretaceous along the same transect. $\mathrm{c}$ ) Cross section from 3-Dimensional seismic data with a graben structure on top of the updoming, faults (white). The question marks symbolize the lack of seismic information of the uppermost $300 \mathrm{~m}$ b.s.l. The arrow marks the position of the river Hunte.

the area of Barnstorf and north of it.

This field evidence at the river Hunte is corroborated by experiments and other field observations of Ouchi (1985) and Schumm (1986), Schumm \& Spitz (1996) who showed that rivers respond to local uplift by incision and formation of terraces, whereas subsidence causes filling and widening of the alluvialplain.

If the updomed area was already a positive topographic high during the Pleistocence the rivers would 
have bypassed this obstacle. In contrast, they have been focussed in this particular area. 3-DimensionalSeismic-Data (kindly provided by the oil company Wintershall-AG), show a graben structure on top of the dome (Fig. 3c). It is unknown as yet if deep faults reach the surface, because the resolution of the 3-D seismic data is inadequate for the uppermost $300 \mathrm{~m}$. The setting is similar to the graben structure on top of the Verden diapir (Fig. 4a). Here the shallow 2-D seismic data shows that the faults on the flanks of
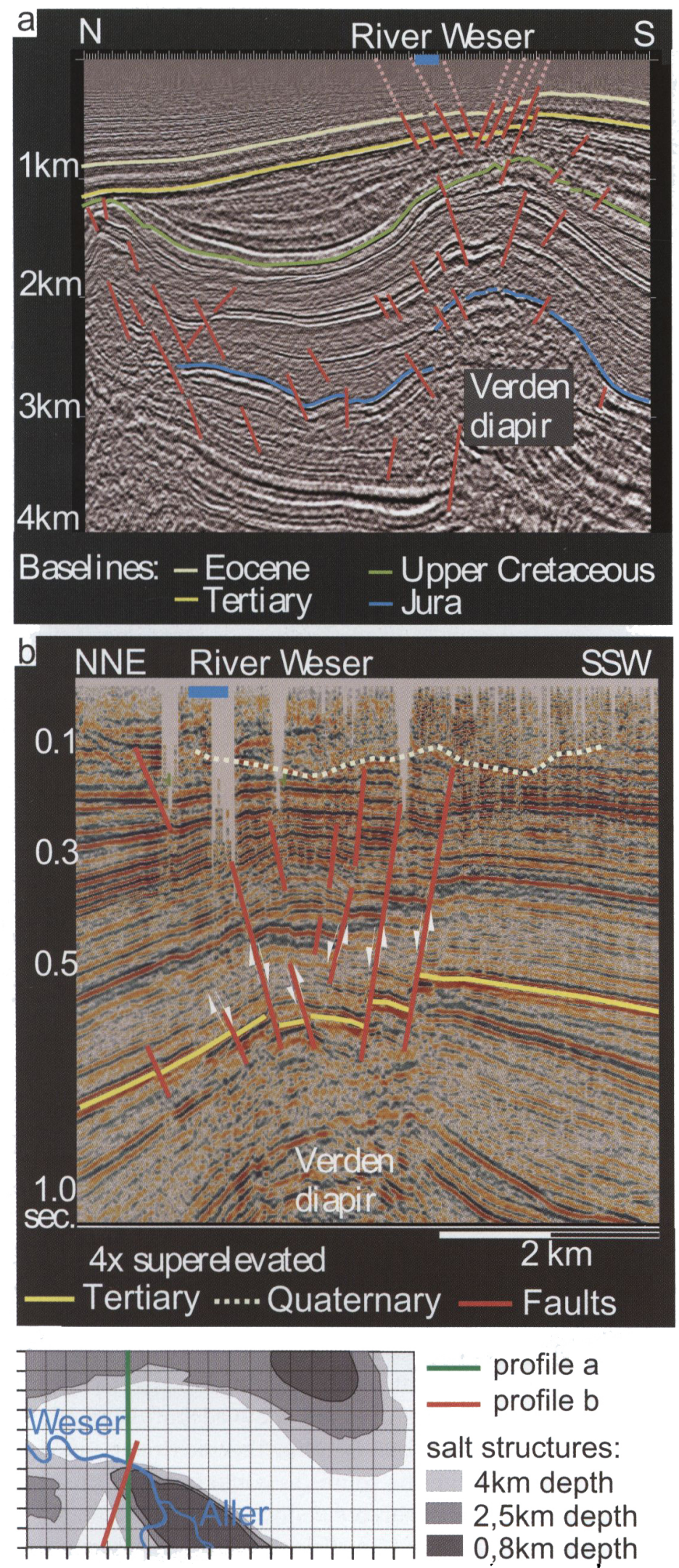

- profile b

salt structures:

$4 \mathrm{~km}$ depth

$2,5 \mathrm{~km}$ depth

$0,8 \mathrm{~km}$ depth

Fig. 4. a) 3-dimensional and b) 2-Dimensional seismic reflection profile of the northwestern sector of the salt diapir at Verden (working area 2), c) location of profile. 
such a graben at $300 \mathrm{~m}$ depth can quite likely reach the surface (Fig. $4 \mathrm{~b}$ ). We assume similar near surface faults also in the area of Barnstorf.

\section{Halokinetic processes}

Working area 2 is situated at the confluence of the rivers Aller and Weser, about $20 \mathrm{~km}$ southwest of the city of Bremen. 3-D seismic data of the oil company RWE/DEA show a salt diapir at a depth of $250 \mathrm{~m}$, exactly below the confluence of the rivers. The Tertiary strata located on top of the diapir and at its northwestern flank reveal a local graben system caused by extensional stress during halokinesis. A large number of staggered normal faults on the flank of the graben displace the base of the Eocene up to $100 \mathrm{~m}$ (Fig. 4). 3-D seismic data show these faults below $400 \mathrm{~m}$ depth; 2-D seismic data (Fig. 4b) reveal that they reach the base of the Quaternary and indicate a displacement magnitude of $40 \mathrm{~m}$ at $100 \mathrm{~m}$ depth. Unfortunately no information could be obtained from the seismic data for the uppermost $100 \mathrm{~m}$. The faults from the 3-D seismic interpretation were projected to the surface and their distribution was mapped (Fig. 5).

A comparison of the strike direction of these projected faultlines with the morphological pattern on the surface showed a clear connection between the two features. The alluvial plain of the Weser and the Aller in the area of the Tertiary graben system is characterised by abundant depressions, reaching a maximum length of $300 \mathrm{~m}$ and a maximum depth of $3 \mathrm{~m}$. These depressions do not exist outside the graben. Smaller depressions might be only of $1 \mathrm{~m}$ length and $20 \mathrm{~cm}$ depth. The depressions are elongated and show identical strike directions with the faultlines at depth (NW-SE) (Fig. 5). At first these depressions appear to be the result of scouring during ephemeral floods of the rivers at some time during the Holocene. Georadar profiles, however, show that the flat strata of fluvial loam are disrupted up to several meters below the depressions (Fig. 5c). The linearity and the disturbance of the deeper sediments are unlikely to be phenomena of scouring, but could well be caused by active faults at depth. On aerial images (Fig. 5) the depressions are visible as dark or pale anomalies associated with variations of soil wetness, reflecting upward or downward fluid flow. These anomalies in soil wetness do not only cause vegetation anomalies (e.g. lines of green grass on a brownish meadow, observed north of the Weser (Seelos, 2000)) but could also cause preferential sites for scouring and erosion during flood events, i.e. recent river dynamics might have led the depressions to form at the location of anomalous physical properties of the underlying strata.
As we regard tectonics to principally control this pattern we call these local and elongated depressions 'Linear Sinking Structures - LSS'.

\section{Subrosion}

On top of the saltdiapir of Wedehof (working area 3, Fig. 1) is a morphological high ( $\max .72 .5 \mathrm{~m}$ a.s.1.), which Liedtke (1980) and Kuster \& Meyer (1993) regarded as part of a middle Saalian endmoraine lobe (Fig. 1). A deep depression ( $31 \mathrm{~m}$ a.s.l.) in the center of the morainic high is caused by subrosion of the uppermost part of the Wedehof Diapir, which is well studied, because it is associated with an extensive gas field. The rim of subrosion is visible in the flowdirection of the abundant small dry valleys of creeks that drained the topographic high (Fig. 6).

The entire Wedehof high is located above a tunnel valley of some $300 \mathrm{~m}$ depth (Fig. 6), formed by meltwater below an Elsterian age glacier. The process of tunnel valley formation was recently discussed by Piotrowski (1997) but the regular SW-NE oriented pattern in the distribution of the tunnel valleys remains largely unexplained. They are widespread all over northern Germany, Netherlands and the North Sea and usually form the base of Quaternary strata (Schwab \& Ludwig, 1996). The local height at Wedehof (diameter of $9 \mathrm{~km}$, Fig. 6a) rises up to $73 \mathrm{~m}$ a.s.l. and shows a subrosion depression of some $30 \mathrm{~m}$ in its center. The precise match of the round topographic anomaly over the salt diapir (black oval in both Fig. $6 a$ and $b$ ) is unlikely to be coincidental. One explanation could be a local uplift of about $50 \mathrm{~m}$ since the Elsterian glacial, i.e. synchronous displacement of the base of the tunnel valley and topographic elevation. Alternatively, the Elsterian glacier and its subglacial meltwaters were in close contact with the diapir, which acted as a barrier for further southward movement of the ice. In this case, the location and deposition of the high moraines (mostly meltwater deposits, with a late glacial flowmoraine on top (Lehne, 2000) were determined by the obstacle of the salt diapir. The role of diapirs in the location of moraines was demonstrated by Teichmüller (1948) for the Segeberger salt diapir and recently suggested again by Schirrmeister (1999) as a widespread phenomenon in northern Brandenburg.

Additional evidence for the obstacle scenario comes from the flow direction of meltwater deposits in several sandpits around the Wedehof diapir. Flow direction of channels within the meltwater sands is not directed to the south (as could be expected from a continuous pushmoraine lobe) but follow the topographic gradient, i.e. flow even to the north and 


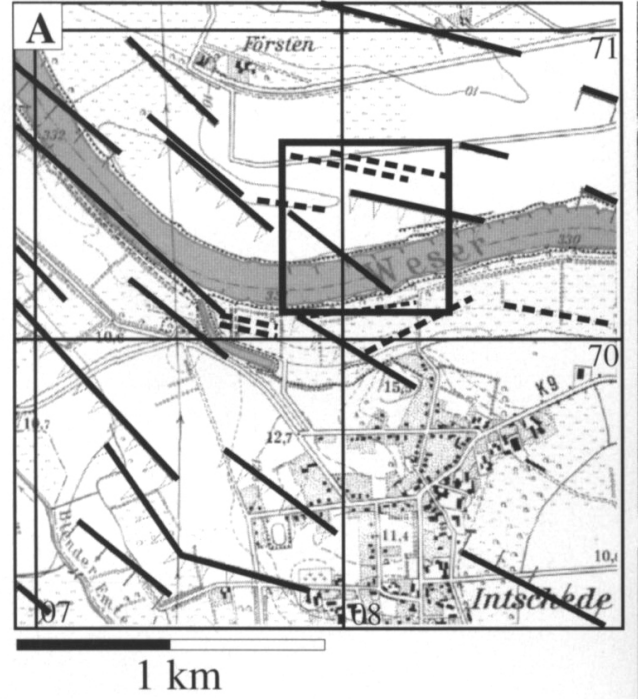

- projected faultlines

--.-. linear sinking struktures LSS

A $\vdash$ B georadar profiles

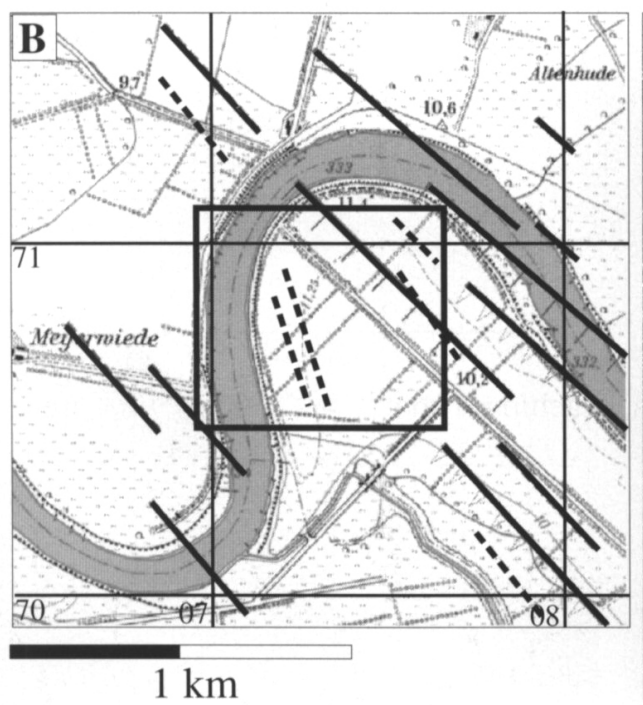

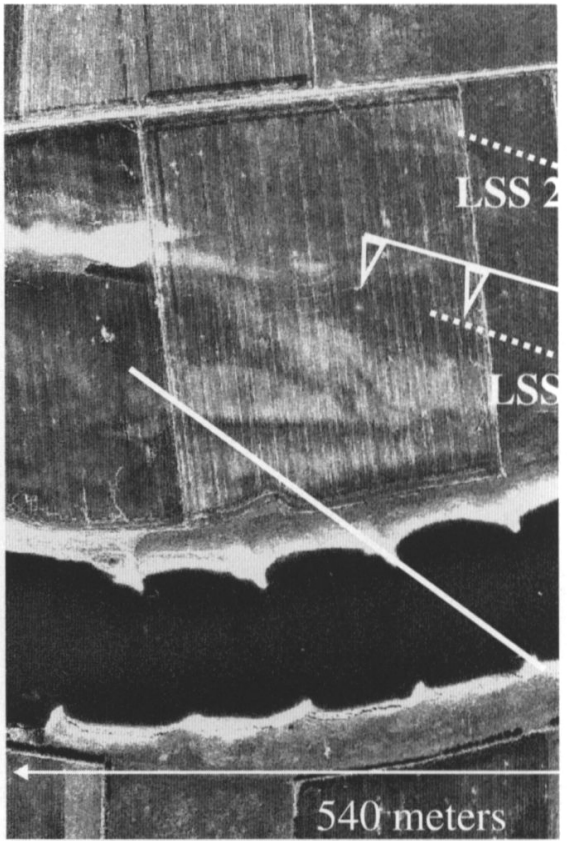

540 meters

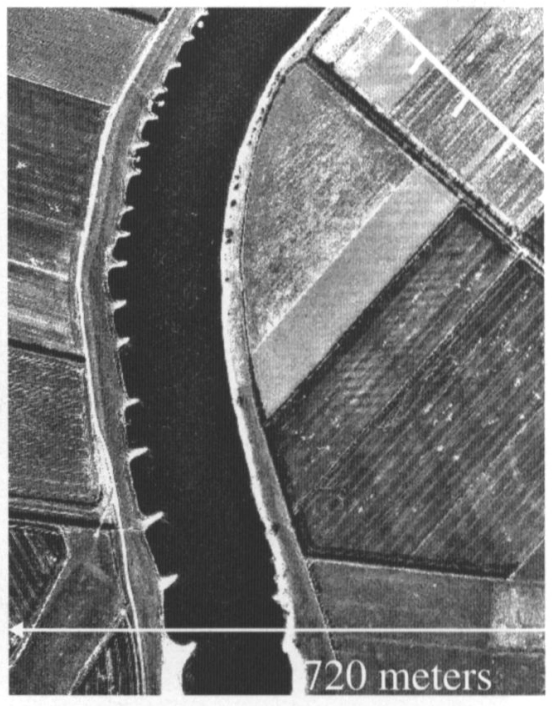

C

236 meters (172 degrees)

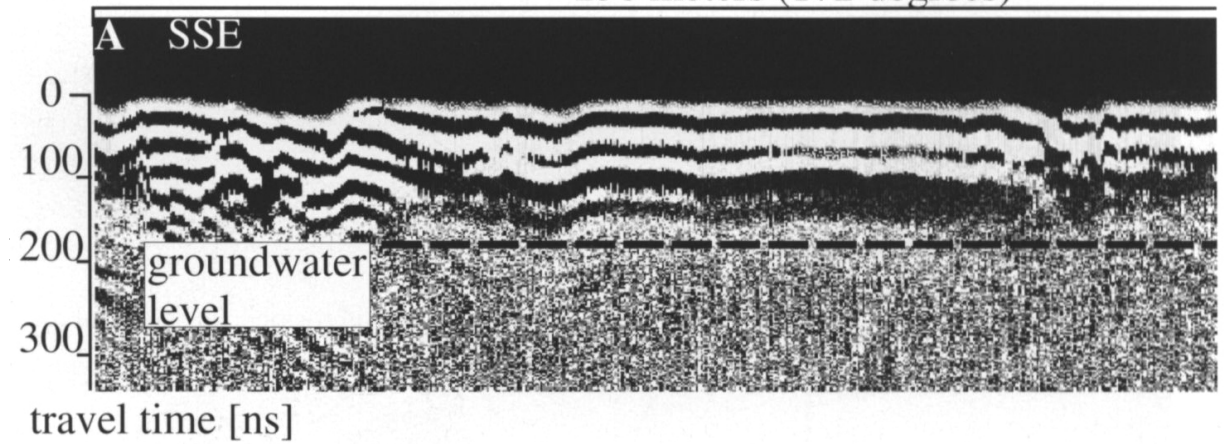

Fig. 5. a, b) Projected (from Fig. 4) fault lines, topographic map and aerial photograph of the river Weser alluvial plain, c) ground penetrating radar $(25 \mathrm{MHz}$ ) of linear sinking structures (LSS) near to projected fault lines (profile A-B on Fig. 5a).

northeast of the moraine (Fig. 6a). If these channels reveal the same age as the meltwater sands, it is most likely that the topographic anomaly was already effec- tive by the Saalian and the obstacle of the diapir caused the anomalous shape of this elevation. If the channels in the sandpits are significantly younger (for 


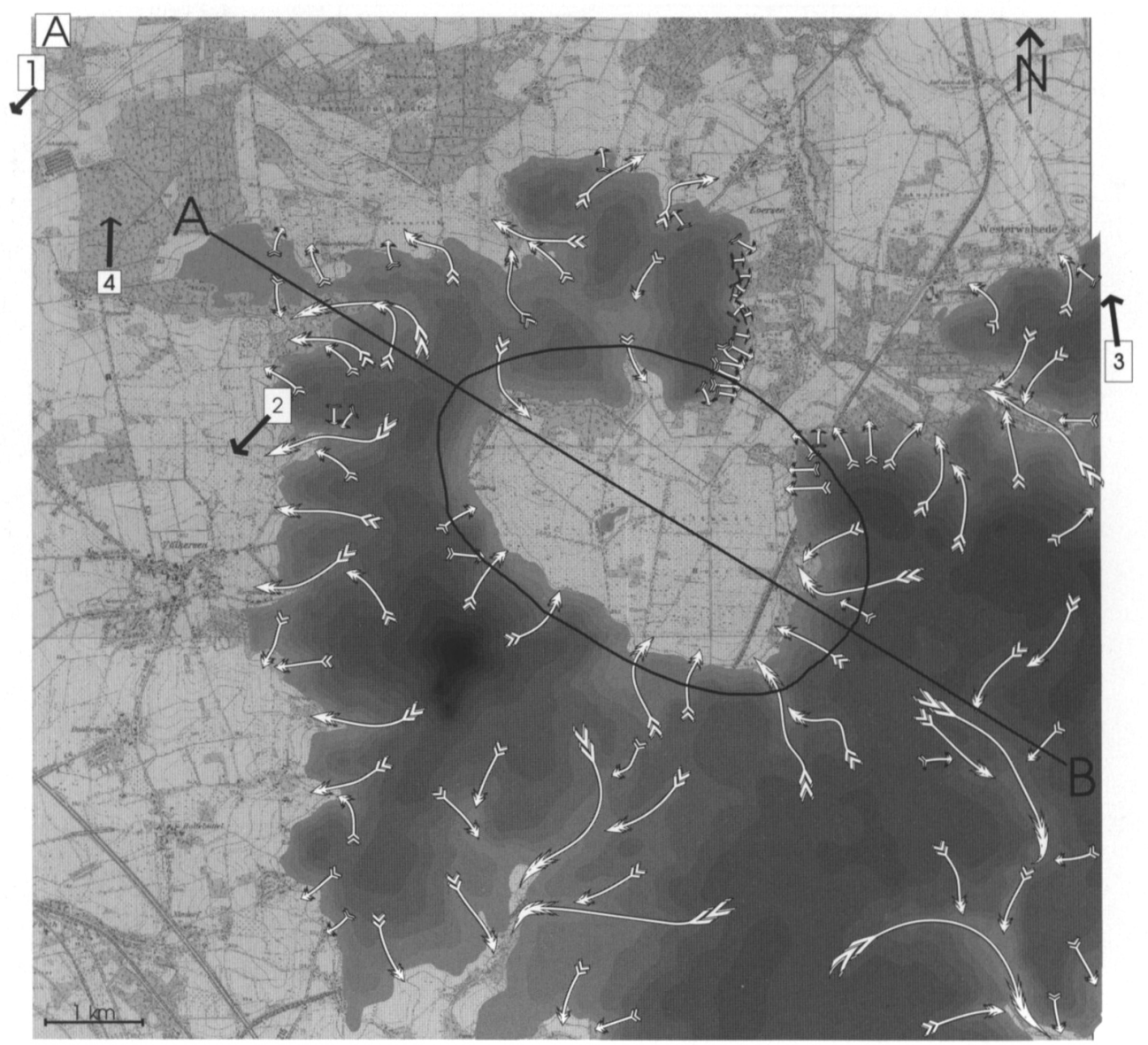

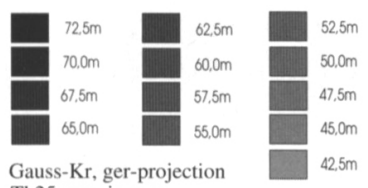
Tk25 mosaic-map
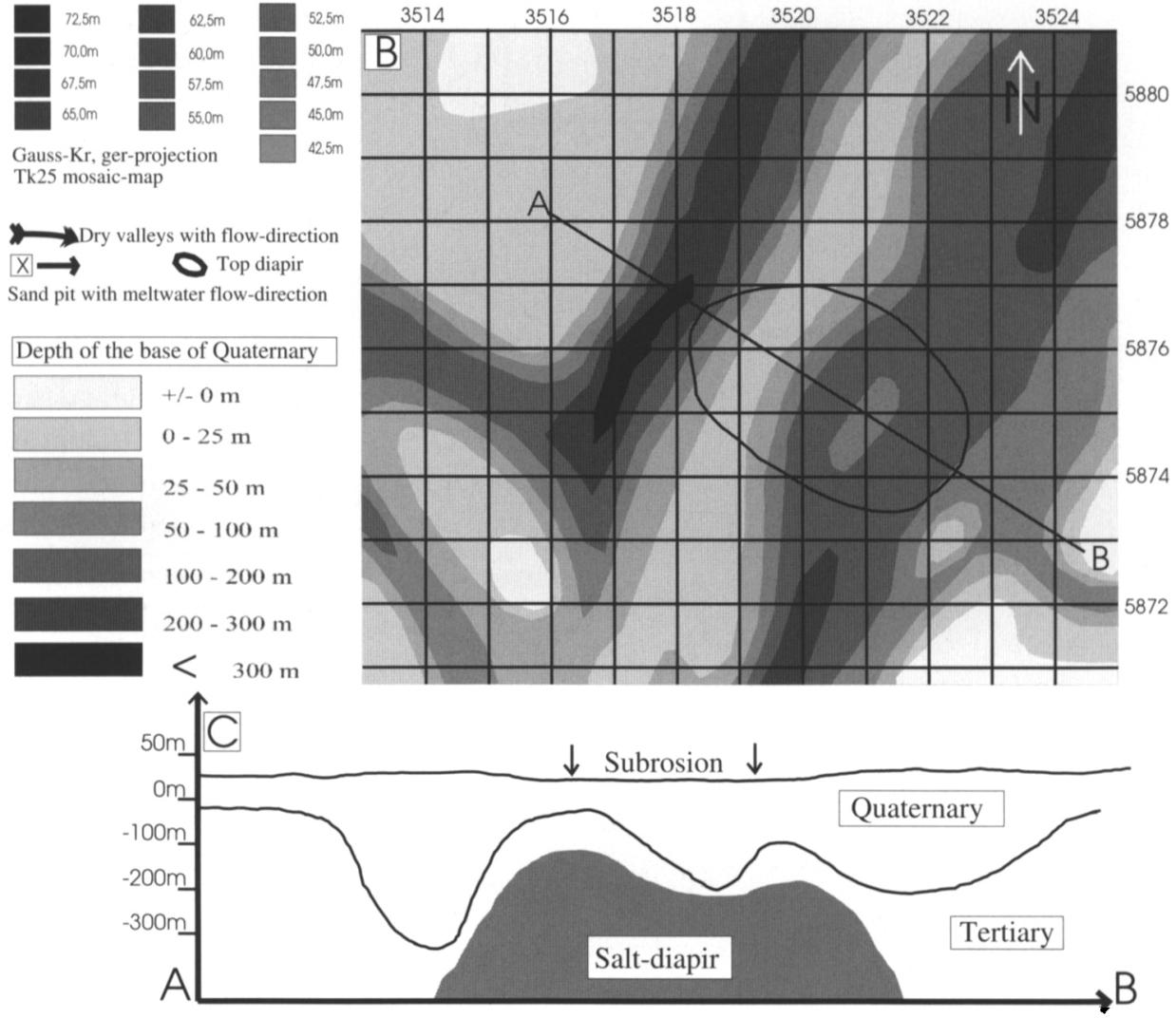

Fig. 6. a) Topographic height around the Wedehof diapir with flow direction along dry valleys (white arrows) and flow direction of channels (age unknown) in the Saalian meltwater sands. The black oval delineates the top of the diapir. b) Depth of the base of the Quaternary, formed by deep tunnel valleys of Elsterian age. c) Cross section AB over the Wedehof diapir. 
example Weichselian stage 3 deposits, called Talsande) than the Saalian meltwater deposits, we must conclude that late Pleistocene halokinesis caused the high elevation of the Wedehof moraines. Several optically stimulated luminescence (OSL) dates to determine the age of the channel sediments are under preparation and may determine which of the two alternatives formed the Wedehof highs (halokinesis or ice-salt contact).

\section{Tectonic faults}

The fourth working area near Lake Plön (Großer Plöner See) is located in the eastern part of Schleswig Holstein (Fig. 1). The lake has a surface area of 30 $\mathrm{km}^{2}$ and a maximum waterdepth of some $60 \mathrm{~m}$. The landscape around the lake is dominated by a lobe of large moraines of Weichselian age, consisting mainly of melt-water-sands. The lake is considered to have been formed by a large Weichelian glacier, approximately 15,000 years ago. The lake is fed and drained by the river Schwentine and some minor creeks.

The Schwentine follows an obvious lineament after leaving the lake in the northwestern corner (Fig. 7). Other lineaments can be observed along the western and eastern lakeshore, which run parallel $\mathrm{S}-\mathrm{N}$ over a distance of several kilometers. It is rather unlikely that the formation of such lineaments is exclusively due to a Weichselian ice lobus. Comparing these morphological lineaments with the depth of Tertiary strata and the position of faults as published in the Tectonic Atlas of NW Germany (1996) leads to a clear picture. The base of the middle Eocene is at less than $200 \mathrm{~m}$ depth on the eastern side of the lake (Ostholstein Platform), whereas the lake itself is located immediately above the flank of the Ostholstein Trough, which has a maximum depth of $1250 \mathrm{~m}$ just west of the lake. The angle of this slope is about $20^{\circ}$, and two large faultlines parallel the eastern shore of the lake. No seismic data are available for the area below the lake. It is thus unknown whether there are more faults in the slope directly below the lake. The southern tip of the lake is clearly centered in a local graben structure, which parallels the lineaments of the western and eastern shoreline. Similarly, the northwestern sector of the lake parallels the flanks of another graben of Tertiary age running WNW-ESE. The linear sector of the river Schwentine flows exactly along the line where the northern graben flank cuts the surface.

From the comparison of lineaments alone, it appears most likely that Tertiary age tectonic structures control the shape and location of the lake. The oldest

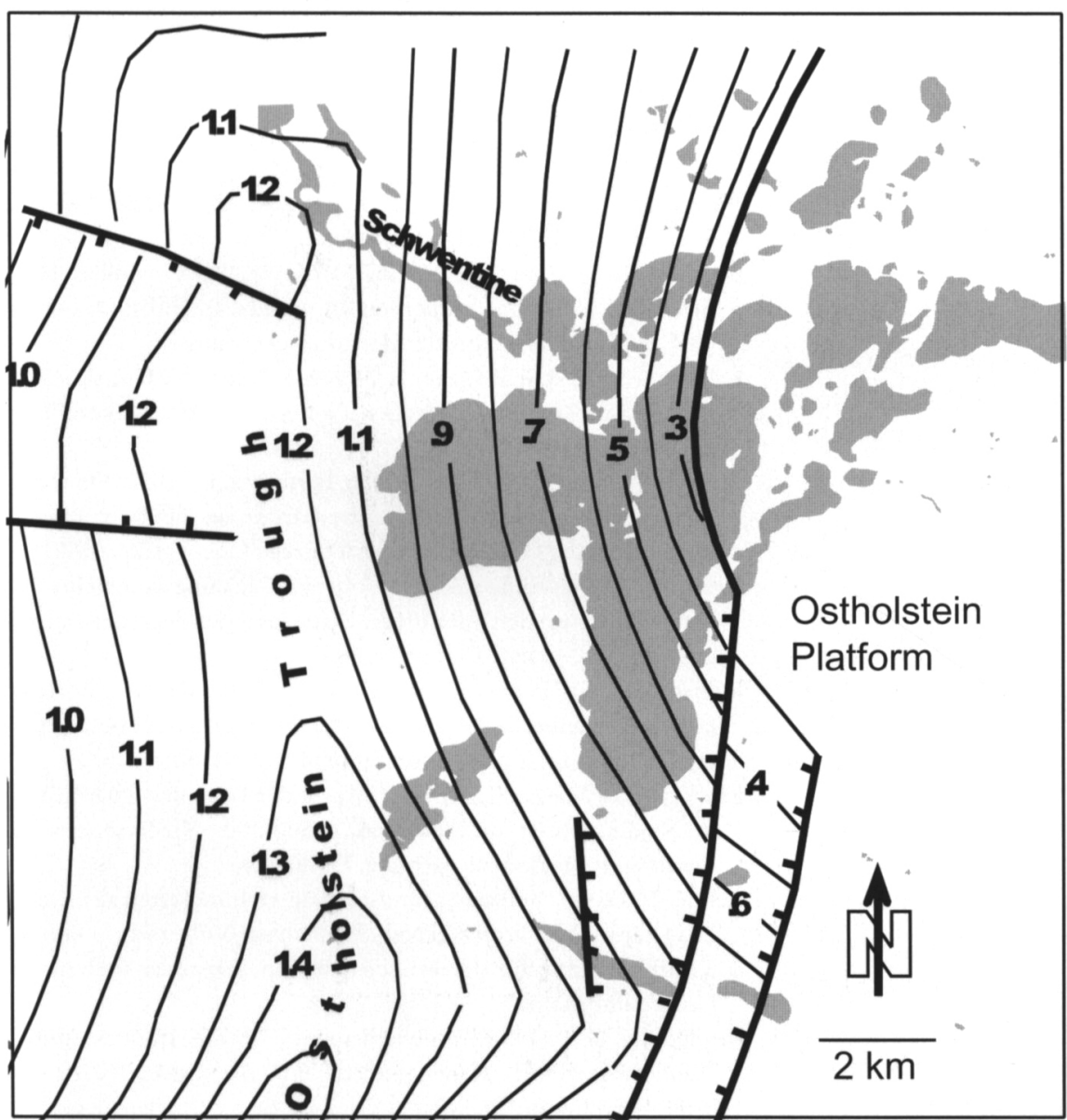

Fig. 7. 'Großer Plöner See' (Lake Plön) with depth $(\mathrm{km})$ of the base of the middle Eocene - Lower Oligocene (from Tectonic Atlas of NW-Germany, 1996) and faults at that level. 
lake sediments have a ${ }^{14} \mathrm{C}$ age near 12.000 years (Erlenkeuser \& Willkomm, 1979), i.e. the lake formed immediately after the retreat of the large inland glaciers. It is quite possible that the lake was indeed filled with ice during the glaciation, but the ice sunk into the ground along inhomogeneities of the upper crust. Piotrowski (1997) showed that the late glacial ice in this area had a thickness of $200 \mathrm{~m}$ (warm ice) to 1000 $\mathrm{m}$ (cold ice). Thus, the isostatic sinking of the land surface must have been between $70 \mathrm{~m}$ and $300 \mathrm{~m}$, and pre-Quaternary extensional faults are likely to have been activated in front of the inland glacier (Johnston et al., 1998).

\section{Discussion}

The morphological effect of young subrosion of salt and gypsum is obvious for the Wedehof diapir, and has been reported at various other locations in the North German Basin. The existence of recent active diapirism is however much debated, in particular in the context of nuclear waste storage in the salt diapir of Gorleben. The seismic profiles of the two salt diapirs of Wedehof and Verden show no unequivocal evidence for ongoing halokinesis with rates more than hundredths of a millimeter per year (the background value as given by Jaritz, 1980, for salt diapirs which are not in a diapiric stage). The linear lightness anomalies on the aereal photographs, however, reveal clearly that the faults of the graben at the Verden diapir act as routes for active fluid flow. The mechanism driving the fluids could be halokinetic, but more likely the occurrence of strong tides, river floods, compaction of Tertiary graben sediments, or changes in the overall stress field could also cause such fluid migration. The updoming of Barnstorf is quite likely to be related to the overall stress field, as the thrust faults in the southern sector of profile A-B-C in Fig. $3 \mathrm{~b}$ dip towards the south and might be seen in the context of the Alpine nappes pushing northwards during the Cenozoic. Deep crustal processes could also play a role for the formation of Lake Plön. The N-S-striking fault along the eastern shore of the lake offset all strata from the Tertiary down to the base of the Permian at $6 \mathrm{~km}$ depth. Offset magnitudes for the Lower Permian (Rotliegendes) sediments are about $500 \mathrm{~m}$ (Tectonic Atlas NW Germany, 1996). The Upper Permian salts (Zechstein) are here at a depth of $2400 \mathrm{~m}$ and form a N-S-stretched pillow. It is not jet known whether the formation of the Tertiary graben structure at the southern tip of the lake was caused by this saltdome or by the deep crustal fault.

Notwithstanding the ambiguous explanations for the processes causing young crustal movements, it ap- pears quite clear that there is evidence of late Pleistocene and recent movements in the upper crust. Lakes and rivers follow such structures.

The coincidence of the topographic high of the Wedehof moraines and the underlying Wedehof diapir shows that the Pleistocene continental glaciers also interacted with the diapirism. Glacio-isostatic adjustments of the land surface after the retreat of the large inland glaciers must have resulted in very complex morphological patterns. The principles of such patterns can be detected when surface morphology and high resolution seismic information are combined with remote sensing data in a modern GIS system. Our first results on this basis show that the rivers, lakes and surface morphology of the North German basin is not static, but dynamic with recent/subrecent tectonic or halokinetic movements of yet undetermined magnitude.

\section{Acknowledgements}

We are grateful to Anne Mather for a carefull review and to the RWE/DEA and Wintershall AG who allowed to study their seismic data and gave permission for publication. D.R. Bridgland carefully improved the English of the manuscript. This paper is a contribution to IGCP 449 'Global Correlation of Late Cenozoic fluvial deposits'.

\section{References}

Boigk, H., 1981. Erdöl und Erdgas in der Bundesrepublik Deutschland. Enke Verlag (Stuttgart).

Caspers, G., Jordan, H., Merkt, J., Meyer, K.D., Müller, H. \& Streif, H., 1995. Niedersachsen. In: Benda, L. (Ed.): Das Quartär Deutschlands. Gebrüder Borntraeger (Stuttgart).

Erlenkeuser, H. \& Willkomm, H., 1979. ${ }^{13} \mathrm{C}$ und ${ }^{14} \mathrm{C}$ Untersuchungen an Sedimenten des Großen Plöner Sees. Arch. Hydrobiologie $85 / 1: 1-29$.

Ihde, J., Steinberg, J., Ellenberg, J. \& Bankwitz, E., 1987. On recent vertical crustal movements derived from revellings within the terretory of the G.D.R. Gerlands Beiträge Geophysik: 206-217.

Jaritz, W., 1980. Einige Aspekte der Entwicklungsgeschichte der nordwest-deutschen Salzstöcke. Zeitschrift der deutschen geologischen Gesellschaft 131:387-408.

Johnston, P., Wu, P. \& Lambeck, K., 1998. Dependence of horizontal stress magnitude on load dimension in glacial rebound models. Geophysical Journal International 132, 41-60.

Kuster, H. \& Meyer, K.D., 1993. Karte der Lage der Quartärbasis in Niedersachsen und Bremen, 1:500.000. Niedersächsisches Landesamt für Bodenforschung, Hannover.

Lehné, R., 2000. Subrosion und jüngste Hebungsraten des Wedehof-Diapirs im Projektgebiet Posthausen-Völkersen. Diploma Thesis. Institut für Geowissen-schaften Johannes GutenbergUniversität Mainz.

Leydecker, G., 1999. Erdbebenkatalog für die Bundesrepublik Deutschland mit Randgebieten für die Jahre 800-1994. http://www.bgr.de/quakecat. 
Liedtke, H., 1981. Die nordischen Vereisungen in Mitteleuropa. Forschungen zur Deutschen Landeskunde 204, Selbstverlag Zentralausschuß für Deutsche Landeskunde-Trier.

Ouchi, S., 1985. Response of alluvial rivers to slow active tectonic movement. Geological Society of America Bulletin 96: 504-515.

Piotrowski, J.A., 1997. Subglacial hydrology in northwestern Germany during the last glaciation: groundwater flow, tunnel valleys and hydrological cycles. Quaternary Science Reviews 16: 169185.

Preussische Messtischblätter, 1898. Königl. Preuss. Landesaufnahme $1: 25.000$. Hannover, Niedersächsisches Landesverwaltungsamt - Landesvermessungsamt.

Ross, P.-H., 1998. Salzaufstieg und Geländemorphologie in Schleswig Holstein - der Segeberger Salzstock und seine schutzwürdige Karstiandschaft. Jahrbuch für den Kreis Segeberg. Verlag C.H.Wäser (Bad Segeberg),

Schirrmeister, L., 1999. Die Position weichselzeitlicher Eisrandlagen in Nord-deutschland und ihre Bezug zu unterlagernden Salzstrukturen. Zeitschrift für geologische Wissenschaften 27 (5/6): 111-120.
Schumm, S. A., 1986. Alluvial River Response to Active Tectonics. Active Tectonrc Studies in: Geophysical National Academic Press (Washington, D.C.): 80-94.

Schumm, S. A. \& Spitz, W. J., 1996. Geological influences on the Lower Mississippi River and its alluvial valley. Engineering Geology 45: 245-261.

Seelos, K., 2000. Einfluß halokinetischer Prozesse auf die Landschaftsformung im Projektgebiet Völkersen-Verden, Niedersachsen. Diploma Thesis. Institut für Geowissenschaften, Johannes Gutenberg-Universität Mainz.

Schwab, G. \& Ludwig, A.O., 1996. Zum Relief der Quartärbasis in Norddeutschland. Bemerkungen $\mathrm{zu}$ einer neuen Karte. Zeitschrift für geologische Wissenschaften 25 (3/4): 343-349.

Teichmüller, R., 1948. Das Oberflächenbild des Salzdomes von Segeberg in Holstein. Zeitschrift der Deutschen Geologischen Gesellschaft 98: 7-29.

Tectonic Atlas of NW-Germany, 1996. Hannover, Bundesanstalt für Geowissen-schaften und Rohstoffe. 1:300.000.

Walter, R., 1992. Geologie von Mitteleuropa. E. Schweizerbartsche Verlagsbuch handlung. (Stuttgart). 